\title{
A BIZALOM JÓ, DE AZ ELLENÖRZÉS MÉG JOBB? - A MUNKAÜGYI ELLENŐRZÉS SZEREPE A MUNKA VÁLTOZÓ VILÁGÁBAN*
}

\author{
Kanyuk Petra Ágnes ${ }^{1}$
}

\begin{abstract}
Május 1-je alkalmából, ünnepi hangulatban a munkajog két meglehetősen különbözö karakterének párositására teszünk kísérletet. A munkáltatók felett sokszor Damoklész kardjaként lebegö munkaügyi ellenörzés tárgykörének a hazai, valamint nemzetközi tekintetben egyaránt a munkajogi irodalom ,fösodrában” elhelyezkedö atipikus munkaviszonyokkal történö, elsö gondolatra szokatlan párositása ugyanis egy módfelett izgalmas vizsgálatra ad lehetöséget, amelynek végére jutva pedig remélhetöleg nem marad majd kétségünk afelöl, hogy ezen atipikus párosítás különös volta nem Mikszáth-i értelemben értendö, kényszer-házasságnak semmiképp sem nevezhetö; a címadó mondás pedig nemcsak a munkaügyi ellenöröknek tetszhet, hanem az a munka változó világának javára is válhat.
\end{abstract}

\section{A munkaügyi ellenőrzésről}

A munkaügyi ellenőrzés egyfajta speciális rendelkezések alapján folytatott közigazgatási hatósági eljárást takar, amely jelentős szerepet játszik a foglalkoztatásra vonatkozó jogszabályokban megállapított kötelességek betartatásában. A munkaügyi ellenőrzésről szóló 1996. évi LXXV. törvény (a továbbiakban: Met.) rendelkezései szerint az ellenőrzés a foglalkoztatásra irányuló jogviszonyok állami kontrollját jelenti, ilyen jellegünek minősül valamennyi jogviszony, amelyben a szolgáltatás tárgya a foglalkoztató részére ellenérték fejében végzett munka. (Met. 1. § (3)) A jogsértések feltárása a vállalkozások piaci esélyegyenlősége és a munkavállalók garanciális jogainak védelme érdekében is kiemelt jelentőséggel bír. ${ }^{2}$

A munkaügyi ellenőrzés napjainkban betöltött szerepét vizsgáló irodalom a terület alapvetően problematikus pontjaiként a stratégiai megközelítés hiányát, a csökkenő költségvetést és személyzetet, valamint az egyre komplikáltabb szabályozási környezetet emeli ki. Mindezek igencsak kellemetlen incidensekben, gyakorlatokban is testet ölthetnek, hazánkban például visszatérőek a munkaügyi ellenőrök korrupcióval kapcsolatos ügyei, míg Franciaországban egyenesen pattanásig feszült a - munkavállalói érdekek védelmére hivatott „utolsó védőbástyaként" aposztrofált - munkaügyi ellenörök helyzete, olyannyira, hogy esetenként még a testi épségük sem garantált. Témánk szempontjából különösen figyelemre méltó az a megállapítás, amely a helyzet ilyen irányú változását a fokozódó munkaterheléssel, az emberi kapcsolatok meglazulásával, valamint - különösen - a

\footnotetext{
${ }^{*}$ DOI 10.21867/KjK/2017.2.5.

${ }^{1}$ Kanyuk Petra Ágnes, joghallgató, DE-ÁJK

${ }^{2}$ Lásd: Burik (2013): 15-18. old.
} 
részmunkaidős és egyéb „bizonytalan” foglalkoztatási formák elterjedésével hozza összefüggésbe. ${ }^{3}$

Mindezek alapján nem meglepö, hogy egyre élénkebb a megújításra - köztük a mind szélesebb összefogásra - irányuló törekvés, amely az EU munkahelyi biztonsággal és egészségvédelemmel kapcsolatos, 2014-2020-as stratégiájában is helyet kapott. ${ }^{4}$ Alapvető érdekként került megfogalmazásra, hogy a munkaügyi ellenőrökben ne az üzleti működését akadályozó, hanem a szabályok alkalmazását segítố személyeket lássák, továbbá a végrehajtandó cselekvések között helyet kapott erőforrásaik feltérképezése, csere-/képzési programjaik értékelése, a kiszabott szankciók hatékonyságának felmérése is. A reformok hullámában üdítően hat az ún. Latin modell konstrukciója, amely a szabályozást a rugalmassággal ötvözve, a munkaügyi ellenőrzés gazdasági szereplők szükségleteihez való igazítására törekszik, ilyen módon mintegy a szabályos foglalkoztatás kampányának katonáivá alakítva az ellenőröket.

\section{Az atipikus munkaviszonyok}

Az imént bemutatott munkajogi eszköztől eltérően az atipikus munkaviszonyok dinamikus, színes jelensége egy merőben eltérő karakterrel rendelkezik. Ezen foglalkoztatási formákon keresztül a munka és a munkaviszony újraértelmezése a munka világában zajló folyamat velejére mutat rá, a hagyományostól elfordulás, az alternatív, kevésbé kötött jogviszonyok jelentősége ugyanis a XXI. században egyre növekszik, ezzel együtt pedig az egyik legnagyobb kihívást jelenti a hagyományos munkajogviszony köré szerveződő munkajog számára. ${ }^{5}$

A hazai munkajogi szabályozás egyértelmüen törekszik ezen igényeknek a minél szélesebb kiszolgálására: az új munka törvénykönyvéről szóló 2012. évi I. törvény (a továbbiakban: Mt.) fö iránya - hasonlóan a régi törvénykönyv módosításaihoz $-a$ munkaviszony rugalmasabbá tétele, ám azt koncepcionálisan is új keretek közé helyezi. ${ }^{6}$

A kodifikáció idején a kormányzat teljes mértékben felvállalta a munkajogi szabályozás rugalmasítását, mint központi célt, a szabályozási koncepciót pedig a magánjoghoz való közelítés elvi alapjára helyezték.

Az Mt. ennek megfelelően az atipikus munkaviszonyokat is átalakította, bővítve a korábbi kört, valamint hangsúlyosabbá téve a kódex-jelleget, ugyanis a tárgyalt jogviszonyok a törvény végén, külön fejezetben helyezkednek el (Mt. II. rész, XV. fejezet), továbbá ez a fejezet, a munkaerö-kölcsönzést tartalmazó XVI. fejezettel együtt a kódex különös részének is tekinthetö. ${ }^{7}$ A kiemelt szabályozási szerepet egyrészt a korábbi széttagoltság felszámolására, a stabilitásra való törekvés, másrészt az atipikus foglalkoztatási formákon keresztül való munkahelyteremtés lehetősége indokolta, ugyanis hazánkban kiemelt probléma a nagyarányú inaktivitás, az átlagos aktivitásunk $(68,5 \%)$ az uniós $72,4 \%$-os átlag alatti.

\footnotetext{
${ }^{3}$ Kapp (2002): 10-13. old.

${ }^{4}$ Commission européenne (2014): 9-10. old.

${ }^{5}$ Kiss (2015): 216. old.

${ }^{6}$ Kiss (2013): 11-23. old.

${ }^{7}$ Gyulavári - Kártyás (2015): 42-43. old.
} 


\section{Ellenőrzött, feketén foglalkoztatott munkavállalók alakulása 2011-2016 között}

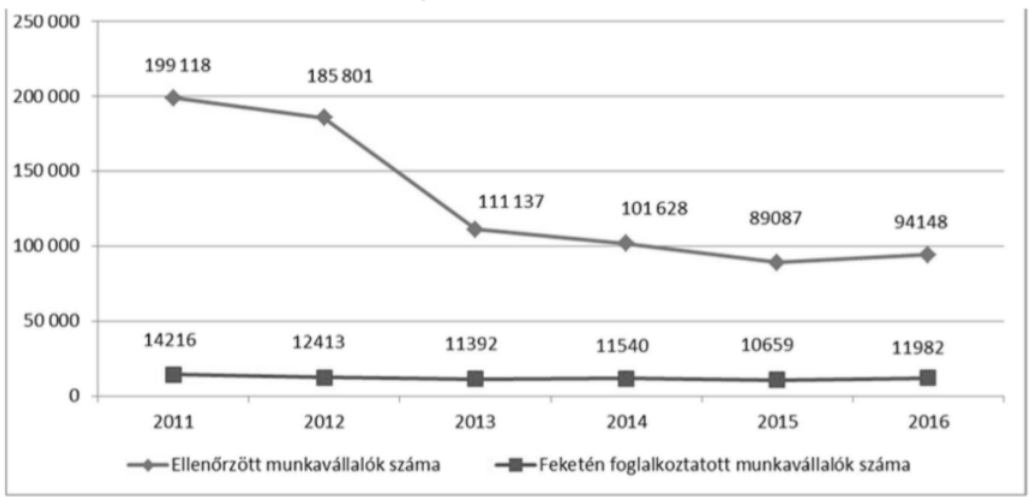

\begin{tabular}{|l|r|r|r|r|r|r|}
\hline & 2011 & 2012 & 2013 & 2014 & 2015 & 2016 \\
\hline Ellenörzött munkavállalók száma & 199118 & 185801 & 111137 & 101628 & 89087 & 94148 \\
\hline Feketén foglalkoztatott munkavállalók száma & 14216 & 12413 & 11392 & 11540 & 10659 & 11982 \\
\hline Feketén foglalkoztatott munkavállalók aránya & $7,14 \%$ & $6,68 \%$ & $10,25 \%$ & $11,36 \%$ & $11,96 \%$ & $12,73 \%$ \\
\hline
\end{tabular}

Forrás: NGM/170321/2016: A 2016-os év munkaügyi ellenőrzési tapasztalatai alapján

EU 28 - Magyarország összehasonlítás (2014)

2. ábra

\begin{tabular}{|c|c|c|c|c|c|}
\hline & Aktivitás & $\begin{array}{c}\text { Foglalkoz- } \\
\text { tatottság }\end{array}$ & $\begin{array}{c}\text { Munka- } \\
\text { nélküliség }\end{array}$ & $\begin{array}{l}\text { Rész- } \\
\text { munkaidő }\end{array}$ & $\begin{array}{c}\text { Határozott } \\
\text { idötartam }\end{array}$ \\
\hline EU 28 & $72.4 \%$ & $65.5 \%$ & $9.5 \%$ & $17.5 \%$ & $12.1 \%$ \\
\hline Magyarország & $68.5 \%$ & $63.8 \%$ & $6.9 \%$ & $4.5 \%$ & $10.2 \%$ \\
\hline
\end{tabular}

Forrás: Randstad (2015): Blanchflower, David G.: Flexibility@ Work 2015: Self-Employment Across Countries in the Great Recession of 2008-2014. Yearly Report on Flexible Labor and Employment. Randstad, Amsterdam, 2015. 109-112. old.

\section{A munkaügyi ellenőrzés és az atipikus foglalkoztatás kapcsolata}

A munkaügyi ellenőrzésről szóló 1996. évi LXXV. törvény (a továbbiakban: Met.) megalkotásakor annak deklarált jogpolitikai célja a fekete-, illetve szürkefoglalkoztatás, pontosabban a jogszabályi feltételeknek nem, vagy nem teljesen megfelelő foglalkoztatás, illetve munkavállalás visszaszorítása volt. Ennél a hazánkban nagyon is jól ismert problémakörnél találjuk a felek kettős kapcsolódási pontját. 
: $\approx$ :

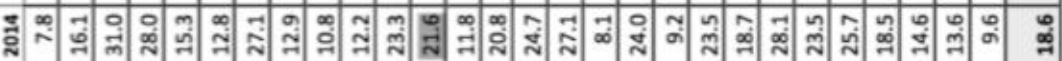
귝 กุ

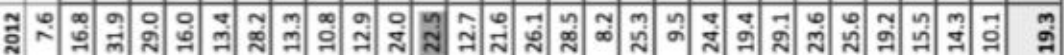
ปี 올 承

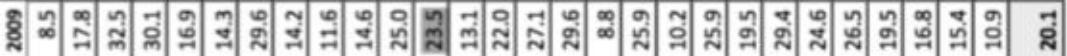

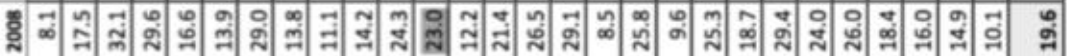

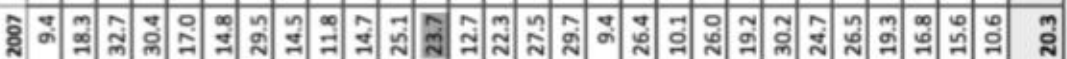

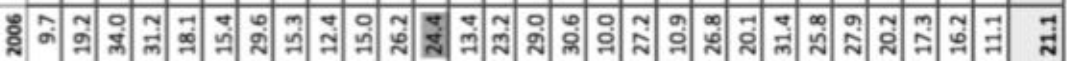
ชి 实审 ర్లి

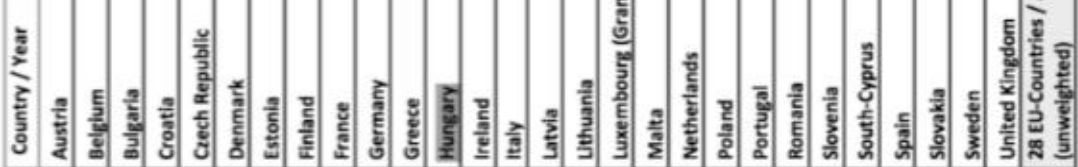


ést érdemel, hogy napjainkban mind az Európai Unió (a továbbiakban: EU) keretein belül, mind azon túl hangsúlyos a jogszabályoknak meg nem felelő foglalkoztatás elleni küzdelem, a probléma definiálására, számszerüsítésére, a minél alkalmasabb eszközök kiválasztására való törekvés. 2015-ben a feketemunka az EU 28 tagállama tekintetében a GDP 18,3\%-át adta, amely, bár komoly problémát jelent, csökkenést mutat a korábbi évekhez képest. Magyarország tekintetében, ezen viszonylatok között 2015-ben 21,9\%kal számolhattunk, amely, bár jóval az átlag felett állt, beleillett a csökkenő tendenciába. Igaz, ez a csökkenés ezen évben megtorpanni látszik és a 2016-os hazai, munkaügyi ellenörzés során nyert adatok további növekedést mutattak a feketefoglalkoztatás tekintetében.

\section{Az atipikus foglalkoztatás, mint szürkébe forduló forma}

A felek közti kapcsolat egyrészt ott jelentkezik, hogy ugyan a munkaadók természetesen nem nyilatkoznak illegális foglalkoztatási szokásaikról, az irodalomkutatás során azonban egyértelművé vált, hogy a fekete-, illetve szürkefoglalkoztatás nagy százalékban takar atipikus formákat, ezért azok gyakorlata a statisztikailag kimutathatónál jóval kiterjedtebb. A lazább szabályok ugyanis igazi „termékenyítő erővel" hatnak a kreatívan szabálytalankodó elmékre, az atipikus körül mindig ott van a szürke valamely árnyalata is. Állami részről mellesleg folyamatosan észlelhető a törekvés az atipikus foglalkoztatási formák tisztítására és ezzel együtt a munkavállalók érdekeinek védelmére. Ilyen jellegü intézkedés volt például, mikor kiterjesztették a fordított áfafizetést a munkaerő-kölcsönzésre és az iskolaszövetkezetekre, amellyel minden bizonnyal a feketefoglalkoztatás egyik fontos forrását apasztották ki.

\section{Az atipikus foglalkoztatás, mint a gazdaság kifehérítésének eszköze}

Az atipikus foglalkoztatási formák azonban eredményes eszközéül is szolgálhatnak a gazdaság kifehérítésének. Vitathatatlan ugyanis, hogy a szabályszerü foglalkoztatás mind adó- és járulékfizetési, mind pedig adminisztratív szempontból is terhet ró a munkáltatókra és a HR szakemberekre, azonban e terhek csökkenthetőek, ha kellő ismeretekkel rendelkeznek a rugalmas foglalkoztatási formákról. Ezen lehetőségek tehát kifejezetten vonzóak lehetnek a szabályozási terhek elől menekülő, nagyobb rugalmasságra vágyók számára.

Ebben a megközelítésben tehát az atipikus munkaviszonyok, azáltal, hogy eredeti rendeltetésüknek megfelelően a változó szükségletek közepette reális és egyben legális alternatívát kínálnak a jogszabályi feltételeknek meg nem felelő foglalkoztatás ellenében, maguk is csatlakoznak a munkaügyi ellenőrzés missziójához. Ugyanis kimutatásra került, hogy a munkajogi szabályozás által kijelölt keret nagy szerepet játszik, annak rugalmasságával arányos az új munkavégzési formák terjedésének intenzitása, amellyel együtt jár a feketemunka arányának csökkenése is. 


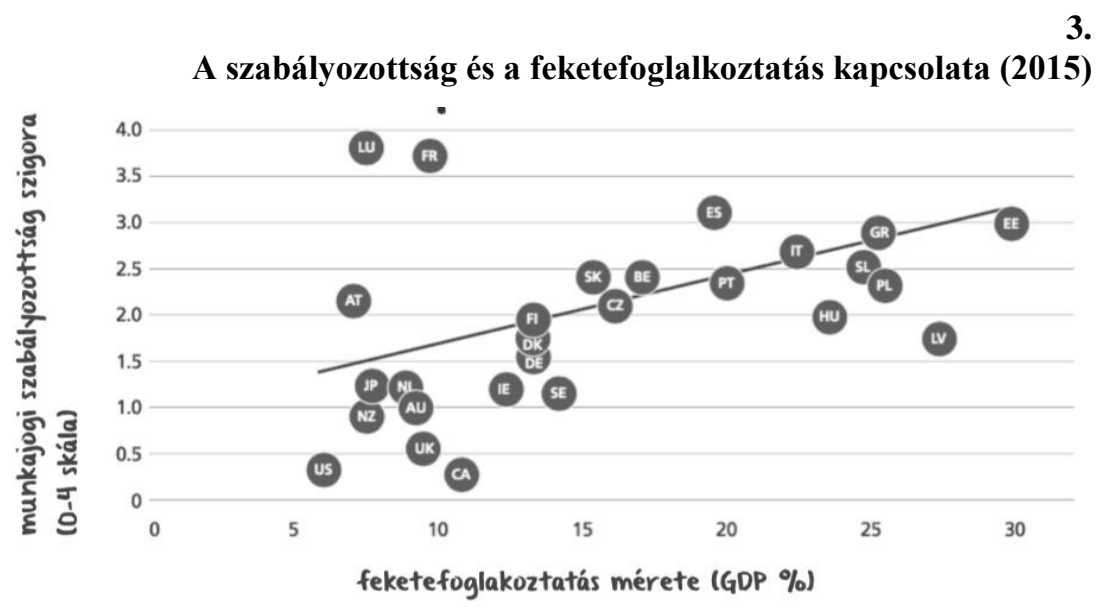

Forrás: Randstad (2016): Goos, Maarten - Konings, Jozef - Rademakers, Emilie: Flexibility@Work 2016: Future of Work in the Digital Age: Evidence from OECD Countries. Yearly Report on Flexible Labor and Employment. Randstad, Amsterdam, 2016. 164. old.

\section{Az atipikus foglalkoztatási formák tipikus hibái}

A felek házasítása, ebből következően az atipikus munkaviszonyok tipikus hibáinak feltárása éppen az imént kifejtett okból bír elemi jelentőséggel. Hiszen a foglalkoztatás új formái csak akkor tölthetik be szerepüket, csak akkor szolgálhatnak gyógyírként a munka világának régi-új problémáira, ha maguk sem piszkolódnak be azután, miután az elmélet síkjáról gyakorlati alkalmazásuk mezejére lépnek; ezen gondolatnak további súlyt adnak Csehov szavai, miszerint: „elmélet gyakorlat nélkül nem létezhet.” Az alábbiakban vessünk tehát egy pillantást - természetesen a terjedelmi korlátok folytán a teljesség igénye nélkül - az atipikus munkaviszonyok munkaügyi ellenőrzések során feltárt, tipikus problémáira.

\section{Az egyszerüsített foglalkoztatás és a bejelentés elmaradása}

E foglalkoztatási forma tekintetében a bejelentés fokozottabb jelentőséggel bír, hiszen maga a munkaviszony a foglalkoztatás bejelentésével jön létre, erre az időpontra tehető annak keletkezése ${ }^{8}$ és sajnos egyben ennek elmulasztása az, amivel a munkaügyi hatóságok az atipikus foglalkoztatási formákat érintő jogsértések között kiemelkedően sokszor találkoznak az ellenőrzések során. Azonban mégis van okunk némi bizakodásra, ugyanis az elmúlt évek tendenciája - amely szerint ez a mulasztás egyre nagyobb mértékben az egyszerüsített foglalkoztatásban fordult elö - megfordultés újra a „hagyományos” munkaviszonyú foglalkoztatás során kerül előtérbe ez a legsúlyosabb munkajogi szabálytalanság. ${ }^{9}$

\footnotetext{
${ }^{8}$ Mt. 202. § (2)

${ }^{9}$ NGM/30844/2015, NGM/160922/2016
} 
A mulasztás hátterében a közterhek befizetésének elkerülésére, illetve az egyszerüsített foglalkoztatás időbeli korlátainak kijátszására irányuló szándék húzódik meg. A munkáltató havi 15 napnál több alkalommal foglalkoztatja a munkavállalót, ám rendes munkaviszonyban történő bejelentés helyett inkább megpróbálja „elbliccelni” az alkalmi munka havi korlátját meghaladó munkanapok bejelentését. ${ }^{10}$

Munkáltatói oldalról jellemzően vélelmezhető a tudatosság. A hatóságok beszámolói szerint a bejelentést számos munkáltató sok esetben percekkel az ellenőrzés megkezdését követően pótolja, mivel ismeri a jogszabályi kötelezettséget, a bejelentés teljesítésének elöírt módját és már a munka megkezdése előtt rendelkezik a bejelentés megtételéhez szükséges munkavállalói adatokkal. Ezek ellenére azonban - bízva a hatósági ellenőrzés adott napokon, időszakban való elmaradásában, illetve abban, hogy nehezen megközelíthető „eldugott helyen” müködnek - azt a bejelentés megtételével megbízott könyvelöirodának csak abban az esetben adja meg, ha már elkerülhetetlen (pl.: hatósági ellenőrzés, munkavállaló kifejezett kérése) a bejelentés megtétele. Jellemző megvalósulási formája a szabálytalankodásnak az is - elsősorban az építöipar területén - mikor a munkáltatók, akik hétköznapokon bejelentetik a munkavállalók egyszerüsített foglalkoztatási jogviszonyát, hétvégén - bízva az ellenőrzések elmaradásában - nem tesznek bejelentést. Gyakran elöfordul továbbá, hogy a munkáltató a tervezett munkaviszony megkezdését megelőzően hosszabb időn át „próbamunkával” igyekszik a munkavállalók (pl.: pultosok, segédmunkások) „képességeit felmérni.”

A munkavállalók nagy része nincs tisztában a munkajogi szabályokkal, amely a munkáltatók részéröl esetleges visszaéléshez, a munkavállalók tudatlanságának kihasználásához vezethet. Természetesen ennek van másik oldala is, amikor a munkavállaló tisztában van az elöírásokkal, de állását féltve saját érdekében nem mer fellépni. A tanúként meghallgatott munkavállalók nagy része - a nyilatkozatok szerint - a munkaügyi ellenőrzés napján kezdett dolgozni (,ma van az első munkanapom”, „csak ma kezdtem”, „ma jöttem elöször dolgozni”, stb.); ennek ellenére a munkaügyi hatóság azon kérdésére, hogy meddig tart a munkaidő, többen is azt nyilatkozták, hogy az „változó (néha nyolc, néha kilenc órát szoktam dolgozni)”.

\section{A munkaerö-kölcsönzés és a három dobogós szabálytalanság}

Ezen konstrukció a tradicionális munkajogviszonytól eltérő foglalkoztatási módszerek egyik karakterisztikus fajtája, sajátos felépítése, részletesebb szabályozása nemcsak az Mt.-ben tette indokolttá a külön fejezetbe foglalását (Mt. II. rész, XVI. fejezet) hanem a munkaügyi ellenőrzés tárgykörei között is külön pontot szenteltek neki (Met. 3. § (1) k) pont) sőt, még az alkalmazható szankciók is szélesebbek az átlagosnál. (Met. 6. § (1) a), f) pont, 6/A. § (1) d) pont, 7. § (1) a) pont). Mindezek alapján nem ér bennünket meglepetésként, hogy a konstrukció esetében a szabálytalanságok tárháza igencsak színes képet mutat.

\footnotetext{
${ }^{10}$ Például: NMH-MMI/140220/2013, vagy FFFO/150214/2014
} 


\section{Munkaerő-kölcsönzéssel kapcsolatos szabálytalanságok (2015)}

4. ábra
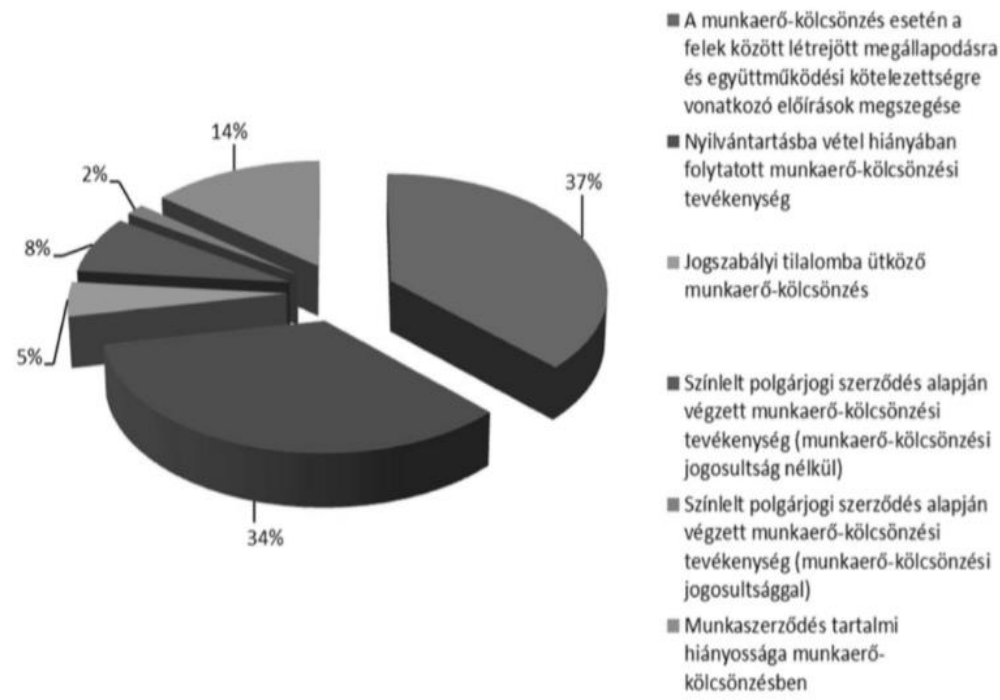

Forrás: NGM/150615/2015: Összefoglaló jelentés a munkaerö-kölcsönzéssel kapcsolatos célvizsgálat tapasztalatairól [2015. március 23. - április 17.] alapján

A jogsértések sorában a 2015-ös munkaerö-kölcsönzéssel kapcsolatos célvizsgálat adatai szerint a harmadik helyet foglalják el a jogszabályi tilalomba ütköző munkaerökölcsönzés esetei (Mt. 216. § (1)) valamint a továbbkölcsönzés tilalmának megszegése (Mt. 216. § (2)). Utóbbi gyakran úgy valósul meg, hogy azt igyekeznek kirendeléssel leplezni, amelyet illetỏen kreatív és kitartó megoldásokkal találkozhatunk. Például egy ilyen eset során tartott munkaügyi ellenőrzés egészen a Legfelsőbb Bíróságig jutott, ahol végül megállapítást nyert, hogy a munkaerő továbbkölcsönzésének tilalmába ütközik az is, ha a munkaerö-kölcsönzésre szólóan kötött munkaszerződésben nem a kölcsönvevő, hanem egy harmadik munkáltató telephelyét jelölik meg a munkavégzés helyeként és a munkavállalók tényleges foglalkoztatása is ott történik. ${ }^{11}$

Kölcsönbeadó nem lehet bármely munkáltató, hanem csak az, aki eleget tesz az erre vonatkozó külön jogszabályi feltételeknek, és akit kérelmére az állami foglalkoztatási szerv felvett a kölcsönbeadók nyilvántartásába (Mt. 215. § (1)). Az ez utóbbi feltétel hiányában folytatott munkaerö-kölcsönzési tevékenység a munkaviszonnyal kapcsolatos legsúlyosabb jogsértésnek minősül, gyakoriságát tekintve pedig ez a második legtöbbször előforduló szabálytalanság. A megvalósulás jellemző formája a teljes illegalitás, amikor a kölcsönbeadóként szereplő céget eleve nem vették nyilvántartásba, de gyakori a féllegális, vagy formailag legális keretek közti megvalósulás is. Előbbire jellemző példa az, mikor a nyilvántartásba vett cég székhelye székhelyszolgáltatónál van bejegyezve, az ellenőrzés során felkutatása azonban eredménytelen, „postafiók cégként" lényegében nem is létezik; utóbbira pedig az, amikor a kölcsönbe adó

\footnotetext{
${ }^{11}$ EBH 2007. 1641, bővebben a döntésről lásd: Kovács (2013): 22. old.
} 
munkáltatók jelentős része csak a munkaszerződések megkötésének és a bejelentések megtételének idejére veteti magát nyilvántartásba, majd a munkaerő kihelyezését követően a nyilvántartásba-vétel törlésre kerül.

A munkáltatói szerepkör meghatározásában az Mt. alapján a felek megállapodása az elsődleges, ebből következően a munkaerö-kölcsönzési szolgáltatásnak többféle változata alakulhat $\mathrm{ki}$ a piacon. Ebből eredően rendkívül nagy jelentősége van a kölcsönbeadó és a kölcsönvevő közötti együttmüködésnek, a kölcsönös tájékoztatásnak, információcserének is, mindezen elöírások megszegése pedig az első helyen áll szabálytalanságok sorában. A helyzet súlyát jelzik a következmények is: a munkavállaló bejelentésére vonatkozó, valamint a kölcsönbeadó nyilvántartásba vételét igazoló okirat másolata átadásának kötelezettsége például csak abban az esetben terheli a kölcsönbeadót, amennyiben arra a kölcsönvevő igényt tart. Az elvárható gondossági kötelem folytán azonban a jogszerütlen foglalkoztatás következményeiért a kölcsönvevőt is felelösség terhelheti.

\section{Gyakorlat és elmélet határán: a munkaügyi hatóság általi minősítés ki nem használt fegyvere}

A munkaügyi hatóság minősítési jogkörének (Met. 1. § (5)) gyakorlása az atipikus foglalkoztatási formák tekintetében nem ismeretlen. A szeptember 1-jét megelőzően az Mt. hatálya alá tartozó iskolaszövetkezeten keresztüli diákmunkát, annak 2011 előtti szabályozásának - a jelenlegi által felelevenített - hiányossága folytán több esetben is tiltott munkaerö-kölcsönzésnek minősítette. Ehhez képest egyéb esetekben mégsem találkozunk bevetésével, holott ennek az atipikus munkaviszonyok sajátosságaira igen érzékeny eszköznek az alkalmazási lehetősége számos esetben adott volna és vélhetően nagyobb nyomást is jelentene a szabálytalankodókra, mint például a bírságolás. Ilyen értelemben tehát a módszer még az elmélet síkján rostokol, azonban remélni tudjuk, hogy mindez a jövőben változni fog.

Átminősítést lehetne alkalmazni például a határozott idejű munkaviszonyok jogellenes láncolatai, a részmunkaidős kikötés ellenére ténylegesen teljes vagy magasabb heti munkaidőben történő foglalkoztatás, valamint a munkaerő-kölcsönzés olyan eseteiben, amikor a tények összessége alapján arra a következtetésre juthatunk, hogy a munkaszerződéssel nem rendelkezö, vagy illegális kölcsönbeadó által foglalkoztatott munkavállaló valójában a kölcsönvevővel áll munkaviszonyban.

Az ellenőrzés szabályainak kijátszására törekvő technikák vizsgálata szomorú képet tár elénk a valóságról. Messze nem arról van szó ugyanis, hogy a vizsgált atipikus foglalkoztatási formákban, Camus szavaival élve a munkahely medréből kicsapó nagy hivatásokkal találkoznánk, vagy - romantikus képzeteinkből ennél már lejjebb adva - a megmutatkozó szabálytalanságokat Shakespeare-i megfogalmazással még a legkülönb ember által is, természetszerüen elkövetett hibáknak tudhatnánk be.

A különös nász eredményeképpen tehát közelebb kerülhetünk a valósághoz: a tipikus hibák feltárása megteremti a javítás lehetőségét, míg a munkaügyi ellenőrzésnek 
további, hatékony eszközeit fedezhetjük fel. Azonban a munka világának szereplöi felé intézett figyelmeztetés túlmutat a jelenleg hatályos kereteken. Az atipikus menyegzö tapasztalatai alapján ugyanis mindenképp szükséges de lege ferenda átgondolni egyrészt az atipikus munkaviszonyok szabályozását, melyben a tárgyalt formák között nem jelentkezne ekkora szabályozásbeli különbség, a rugalmasság mellett a biztonság oldala is érvényre jutna és igyekezne minél többet orvosolni az ellenőrzések során feltárt problémák közül, hogy ezen foglalkoztatási formák valóban csak a tipikustól, és nem pedig saját maguktól jelentsenek eltérést.

Fontos továbbá a munkaügyi ellenőrzés szerepének a napjainkban érvényesülő trendeknek megfelelően történő átgondolása is, hogy érzékenyebb legyen korunk kihívásaira, a rugalmasságra, a gazdasági érdekekre és mindezt egy, a többi kapcsolódó szervezettel való dinamikus együttmüködésben valósítsa meg, melyhez természetesen a kellő anyagi támogatás sem hiányozhat. Ilyen módon pedig a munkaügyi ellenőrzés valóban a munkavállalói érdekek - ha remélhetőleg nem is utolsó, viszont mindenképpen - védőbástyájaként funkcionálhat.

\section{Források:}

- $\quad$ 1996. évi LXXV. törvény a munkaügyi ellenőrzésről

- 2012. évi I. törvény a munka törvénykönyvéröl

- $\quad$ EBH 2007. 1641

- NGM/150615/2015: Összefoglaló jelentés a munkaerő-kölcsönzéssel kapcsolatos célvizsgálat tapasztalatairól [2015. március 23. - április 17.]

- NGM/30844/2015, NGM/160922/2016

- NMH-MMI/140220/2013: Összefoglaló a munka-és pihenőidő szabályainak érvényesülése tárgyú célellenőrzés tapasztalatairól [2013. október 2 - október 18.]

- FFFO/150214/2014: Összefoglaló jelentés a munkabérrel kapcsolatos szabályok célvizsgálatáról [2014. október 13. - november 7.]

- A fóvádlott adta le a drótot munkaügyi ellenörzés elött. http://hvg.hu/karrier/20131111_A fovadlott_adta_le_a_drotot_munkaugyi_el (2016-08-25)

- Agreement signed: ILO, Dutch govt to help revitalise labour inspection machinery http://tribune.com.pk/story/916622/agreement-signed-ilo-dutchgovt-to-help-revitalise-labour-inspection-machinery/ (2016-08-28)

- Bois, Richard: La Dernière Digue. Documentaire, Kuiv Productions, 1998. http://www.kuiv.com/pages/dernieredigue.htm (2016-08-13)

- Burik Mária: Munkaügyi ellenőrzés. Van, amikor hangsúlyos, néha hangsúlytalan - célok, okok és következmények a munka világában. HR \& Munkajog, 2013/4. sz. 15-18.

- Commission européenne (2014): Communication de la Commission au Parlement européen, au Conseil, au Comité économique et social européen et au Comité des régions relative à un cadre stratégique de l'Union européenne en 
matière de santé et de sécurité au travail (2014-2020). Bruxelles, 6.6.2014 COM (2014) 332 final.

- Doumayrou, Fanny: Qui défendra les inspecteurs du travail? Le Monde diplomatique, No. 705/2012. 4-5.

- Elitélték a korrupt munkaügyi ellenöröket. https://www.profession.hu/cikk/20150715/eliteltek-a-korrupt-munkaugyiellenoroket/5632 (2016-08-25)

- Gyulavári Tamás - Kártyás Gábor:sẹpiThe Hungarian Flexicurity Pathway? New Labour Code after Twenty Years in the Market Economy. Pázmány Press, Budapest, 2015.

- Gyulavári Tamás - Kártyás Gábor: Effects of the new Hungarian Labour Code: the most flexible labour market in the world? Lawyer Quarterly, No. 4/2015. 233-245.

- https://www.nav.gov.hu/nav/ado/afa080101_hatalyos/2015_januar_1_jetol2 0141222.html (2016-08-13)

- İ́gy trükköznek a cégek - és megússzák ejnyebejnyével. http://www.piacesprofit.hu/kkv_cegblog/igy-trukkoznek-a-cegek-esmegusszak-ejnyebejnyevel/ (2016-08-16)

- Kiss György: A rugalmasság és státuszvédelem egy lehetséges megközelitése. In: Horváth István (szerk.): Tisztelgés: ünnepi tanulmányok Dr. Hágelmayer Istvánné születésnapjára. ELTE Eötvös Kiadó, Budapest, 2015. 214-234.

- Kovács Szabolcs: Az 1992 évi Mt bírói gyakorlatának tovább élése - a munkaerö-kölcsönzés szabályai. HR Munkajog, 3/2013. 19-22.

- Kricskovics-Béli Boglárka: A bejelentés nélküli foglalkoztatás problematikája. http://www.ohe.hu/hrmagazin/cikkek/a-bejelentes-nelkuli-foglalkoztatasproblematikaja (2016-08-13)

- Kulinyi Márton: Tudósitás az "Atipikus és nagyon atipikus munka világa” cimü találkozóról. http://munkavilagamuhely.blog.hu/2015/04/20/atipikus_beszamolo (2016-0815)

- Packard, Truman - Koettl, Johannes - Montenegro, E. Claudio: In From the Shadow - Integrating Europe's Informal Labor. The World Bank, Washington, 2012.

- Piore, Michael J. -S chrank, Andrew: Toward managed flexibility: The revival of labour inspection in the Latin world. International Labour Review, No. 1/2008. 1-23.

- Pirinski, Georgi: Le travail non déclaré prive les gens de droits élémentaires. http://www.europarl.europa.eu/news/fr/newsroom/20160202STO12430/georgi-pirinski-le-travail-non-déclaré-prive-lesgens-de-droits-élémentaires (2016-08-14)

- Randstad (2015): Blanchflower, David G.: Flexibility@Work 2015: SelfEmployment Across Countries in the Great Recession of 2008-2014. Yearly Report on Flexible Labor and Employment. Randstad, Amsterdam, 2015.

- Randstad (2016): Goos, Maarten - Konings, Jozef - Rademakers, Emilie: Flexibility@Work 2016: Future of Work in the Digital Age: Evidence from 
OECD Countries. Yearly Report on Flexible Labor and Employment. Randstad, Amsterdam, 2016.

- Schneider, Friedrich - Buehn, Andreas - Montenegro, E. Claudio: Shadow economies all over the world: new estimates for 162 countries from 1999 to 2007. In: Schneider, Friedrich (ed.): Handbook on the Shadow Economy. Edward Elgar Publishing, Northampton, 2011.

- Schneider, Friedrich: Size and Development of the Shadow Economy of 31 European and 5 other OECD Countries from 2003 to 2015: Different Developments.

http://www.econ.jku.at/members/Schneider/files/publications/2015/ShadEcEur ope31.pdf (2016-08-13)

- Weil, David: A strategic approach to labour inspection. International Labour Review, No. 4/2008. 349-375. 